Archives de sciences sociales des religions

155 | juillet-septembre 2011

Le consensus des experts | Inattendus pèlerinages

\title{
The religious expert in American courts
}

\section{Winnifred Fallers Sullivan}

\section{(2) OpenEdition}

\section{Journals}

Electronic version

URL: http://journals.openedition.org/assr/23305

DOI: 10.4000/assr.23305

ISBN: 978-2-7132-2303-7

ISSN: $1777-5825$

Publisher

Éditions de l'EHESS

Printed version

Date of publication: 30 September 2011

Number of pages: 41-60

ISSN: 0335-5985

\section{Electronic reference}

Winnifred Fallers Sullivan, "The religious expert in American courts", Archives de sciences sociales des religions [Online], 155 | juillet-septembre 2011, Online since 14 November 2011, connection on 19 April 2019. URL : http://journals.openedition.org/assr/23305; DOI : 10.4000/assr.23305 


\section{Winnifred Fallers Sullivan}

\section{The religious expert in American courts}

\section{Introduction}

Expertise is a problem for Americans. Particularly academic expertise; and particularly in public matters. Expertise is considered elitist, and is suspect for that reason, but, more fundamentally, expertise is understood to serve other masters, masters other than the people. Expertise is viewed as un-democratic. ${ }^{1}$ One does want one's doctor to be an expert in the disease for which she is treating you, but one does not want political matters to be decided by experts. Expertise in law falls between these two. One does want experts in DNA analysis to be available in court cases, for the most part, unless it costs the public too much or is too focused on the exoneration of criminals, but the prejudice is that most issues of fact in the courts in the United States are best not decided by experts. ${ }^{2}$ There is an interesting, perhaps ironic, convergence here between popular prejudice and the conclusions of sociologists of knowledge. ${ }^{3}$

1. The classic work on this topic is the much-debated Richard Hofstadter, AntiIntellectualism in American Life, New York, Vintage Books, 1966.

2. This prejudice is also true of legislative legal work. Hence the popularity of laws written by popular vote, such as the awkwardly worded, even incoherent, amendment to the Oklahoma Constitution adopted in the November 2010 election. Question 755 amended the Oklahoma Constitution as follows:

B. Subsection C of this section shall be known as the "Save Our State Amendment".

C. The Courts provided for in subsection A of this section, when exercising their judicial authority, shall uphold and adhere to the law as provided in the United States Constitution, the Oklahoma Constitution, the United States Code, federal regulations promulgated pursuant thereto, established common law, the Oklahoma Statutes and rules promulgated pursuant thereto, and if necessary the law of another state of the United States provided the law of the other state does not include Sharia Law, in making judicial decisions. The courts shall not look to the legal precepts of other nations or cultures. Specifically, the courts shall not consider international or Sharia Law. The provisions of this subsection shall apply to all cases before the respective courts including, but not limited to, cases of first impression.

It is less a law than a salvo in the culture wars.

3. For a discussion of epistemological issues, generally, with respect to expert evidence, see Gary Edmond, "Whigs in Court: Historiographical Problems with Expert Evidence", Yale Journal of Law and Humanities, 14, 2002, 123-75. For an empirical analysis of judicial attitudes toward academic expertise, see Henry F. Fradellaa, "A Content Analysis of Federal Judicial Views of the Social Science 'Researcher's Black Arts”, Rutgers Law Journal 35, Fall 2003, 103-170. 
This essay will consider how this US political and social style is exemplified by the problem of expertise about religion in the context of the American courtroom. The United States is a profoundly do-it-yourself society, not only in politics, but also in religion. After the Revolution, the western part of the country was evangelized, for the most part, by part-time preachers lacking a seminary education, who spoke from the heart and from largely untutored readings of the Bible. As Mark Noll argues in The Scandal of the Evangelical Mind, ${ }^{4}$ a book that arguably describes not just the minds of evangelicals but the minds of most Americans, Americans have come to prefer a style of public engagement which is characterized by a distinctive combination of magical thinking and practical positivism. While not anti-clerical in the European sense, Americans tend toward a religion that is experiential and expressive rather than intellectual, and in which religious authority is located in the individual, wherever one is located along the political or theological spectrum.

The essay will consider, first, briefly, legal rules governing expert evidence, and then, second, consider how evidence about religion functions in US courts, using examples from cases under both the Free Exercise and Establishment clauses of the First Amendment to the US constitution. These cases will be used to illustrate the political and epistemological predicament of such expertise in American courts.

\section{The Rules of Evidence}

It is important, and helpful, first, to put the problem of the religious expert in the wider context of expert witnessing in US courts, an enterprise that is in a state of serious re-examination at the present time. The US is unusual, even among common law jurisdictions, in the extent to which it continues to rely on juries in both civil and criminal matters. Indeed, the rules that govern the presentation of evidence in trials in the United States presuppose a jury, even when no jury is present. ${ }^{5}$ This bias toward the jury trial as exemplary significantly affects the form and style of evidence presented. The bias is for perceptual evidence given in public in court in the first person. It is believed always preferable for the jury-or the judge as fact-finder-to see and hear the witness firsthand, and to see and hear the witness being cross-examined, so that the jury-or

4. Mark Noll, The Scandal of the Evangelical Mind, Grand Rapids, Eerdmans, 1995.

5. This is the case notwithstanding the fact that less than $1 \%$ of American trials are jury trials: The data provide a picture of trends in the state courts that overall bear an unmistakable resemblance to the trends in federal courts we have been examining. The portion of cases reaching jury trial declined from $1.8 \%$ to $0.6 \%$ of dispositions and bench trials fell from $34.3 \%$ to $15.2 \%$. The absolute number of jury trials is down by one-third and the absolute number of bench trials is down 6.6\%. Marc Galanter "The Vanishing Trial: An Examination of Trials and Related Matters in Federal and State Courts”, J. Empirical Legal Studies, 1, 2004, 459-570. For an exemplary account of the nature of the trial and of the adversary process in the United States, see Robert P. Burns, A Theory of the Trial, Chicago, University of Chicago Press, 1999. 
judge-can evaluate the reliability of the testimony herself, using primarily common sense reasoning. All evidence that deviates from this preferred standard, whether documentary, physical, or "scientific", labors under a presumptive handicap. Expert evidence of any kind is thus suspect because it depends on a factual record, as well as disciplinary training and practices, which are located outside the courtroom and therefore largely unavailable to testing before the trier of fact through cross-examination. Expert testimony may also introduce facts and analysis that were not available to the legislator or which support statutory interpretation at odds with the legislator's intention. Finally, and critically, the actual delivery of expert testimony may demand of the expert a level of certainty or a form of expression that is inappropriate to the expert's knowledge, tempting the expert to deliver her opinion in a language and forum foreign to her field of expertise.

The basic evidentiary standards in American trials are logical relevance and materiality. 6 "Materiality requires that the fact any bit of evidence is offered to prove have significance given the legal rule established by the substantive law and provided in the jury instruction. Logical relevance requires that the evidence offered have some logical force in changing the probability of a material fact." 7 Unless there is a specific exception, all relevant evidence is admissible. ${ }^{8}$ Relevant evidence includes testimonial, documentary, and physical evidence concerning the events that gave rise to the litigation, but also testimony and reports by experts that can "assist" the judge and the jury in understanding the evidence.

Two rules primarily govern expert testimony in US Federal Courts, Federal Rules of Evidence 702,703:

Rule 702. Testimony by Experts

If scientific, technical, or other specialized knowledge will assist the trier of fact [judge or jury] to understand the evidence or to determine a fact in issue, a witness qualified as an expert by knowledge, skill, experience, training, or education, may testify thereto in the form of an opinion or otherwise, if (1) the testimony is based upon sufficient facts or data, (2) the testimony is the product of reliable principles and methods, and (3) the witness has applied the principles and methods reliably to the facts of the case.

Rule 703. Bases of Opinion Testimony by Experts

The facts or data in the particular case upon which an expert bases an opinion or inference may be those perceived by or made known to the expert at or before the

6. The actual rules of the law of evidence in US courts differ by jurisdiction. In this essay, for the sake of simplicity, I will be speaking of the evidentiary rules in federal courts. Significant differences exist in and among state courts. The US Constitution also provides some limits as to what evidence can be introduced, particularly in the $5^{\text {th }}$ and $6^{\text {th }}$ amendments. Common law rules of evidence also continue to inform the interpretation of both federal and state codes. For an introduction to the American law of evidence, see Graham C. Lilly, Principles of Evidence, Minneapolis, West Publishing, 2006.

7. Robert P. Burns, "Social Science and the Ways of the Trial Court: Possibilities of Translation”, in E. Mertz and W. Ford, (eds.), The Process of Translation: Law, Social Science, and New Legal Realism, forthcoming, Cambridge, Cambridge University Press, 2011.

8. Federal Rules of Evidence, 402. 
hearing. If of a type reasonably relied upon by experts in the particular field in forming opinions or inferences upon the subject, the facts or data need not be admissible in evidence in order for the opinion or inference to be admitted. Facts or data that are otherwise inadmissible shall not be disclosed to the jury by the proponent of the opinion or inference unless the court determines that their probative value in assisting the jury to evaluate the expert's opinion substantially outweighs their prejudicial effect.

As the language of the rules implies, federal judges in the US are generally understood to have broad discretion in admitting a wide spectrum of what is called "expert" testimony, particularly in bench trials. ${ }^{9}$ They may do so "[i]f scientific, technical, or other specialized knowledge will assist the trier of fact [judge or jury] to understand the evidence or to determine a fact in issue." In practice, judges admit a very wide range of so-called "expert" testimony, on road conditions, on medical treatment, on the psychology of criminals and witnesses, on safety standards, etc. The witnesses providing such testimony may or may not have academic qualifications. It is usually enough if they have some specialized knowledge, even if that knowledge is based in long experience rather than in academic training.

There is increasing concern today, given the technological complexity of our lived environment, as to the capacity of jurors and judges to assess the professional competence of experts and to understand and properly evaluate expert "scientific" testimony. ${ }^{10}$ Much has been written about the deleterious effect of what is sometimes called "junk science". ${ }^{11}$ These legal issues naturally also take their place within a wider intellectual focus on epistemology today.

Formally speaking, the US trial judge is understood to act as "gatekeeper" with respect to expert evidence. The judge decides whether the evidentiary rules with respect to the admissibility of expert evidence have been met, both as to the expert's qualifications and as to whether the evidence itself meets the requirements of the rules as to whether it is relevant and "reliable"-that is, whether it is indeed scientific. The jury decides whether such evidence is credible and determines the weight to be given it. Beginning in the middle of the twentieth century, the accepted judicial standard for the admission of scientific evidence was that it had to be based in "science" that was "accepted in the scientific community." 12 Today, in most US jurisdictions, that conservative standard of

9. A bench trial is a trial without a jury, increasingly common in the US.

10. Some argue that more highly technical matters should be decided by specially trained judges, as are patent matters, for example, rather than by regular civil courts. But this is not an entirely new concern. See Learned Hand, "Historical and Practical Considerations Regarding Expert Testimony", Harvard Law Review, 15, 1901, 40-58.

11. For a particularly egregious example of the devastating effect of the introduction of incompetent expert testimony, see the description of an arson prosecution in a recent New Yorker article. David Grann, “Trial by Fire: Did Texas Execute an Innocent Man?” The New Yorker, September 7, 2009, 42-63. On this case and other persistent issues in the administration of criminal justice in Texas, see gritsforbreakfast blog at http://gritsforbreakfast.blogspot.com/ search/label/Todd\%20Willingham (accessed June 14, 2011).

12. This standard is known as the Frye rule. Frye v. United States, 293 F. 1013 (DC Cir. 1923). 
reliability has been replaced with a theoretically more open-ended and forwardthinking standard that asks whether the evidence has being produced using the scientific "method." 13 Whether this new standard is an improvement, that is, whether it enables the introduction of more useful evidence and whether judges and juries are any better at evaluating this kind of science, is controversial among both academics and lawyers.

Expert testimony in American courts is also distinctive in that it is offered within the context of the adversary trial. Generally speaking, expert testimony in trials in the United States is presented by one of the parties as a part of that party's case. The expert is cross-examined by the opposing attorney in front of the jury-or judge. The rules permit a judge to call her own experts but that rarely happens. It is common, thus, in US trials for there to be what is sometimes called "dueling experts". In other words, for example, as to any particular issue in a legal case, such as the correctness of a decision made by a doctor with respect to a patient's treatment, a medical expert will be presented by each party, one offering the opinion that the doctor's decision was not coincident with best medical practice, and the other offering the opinion that it was. Each side, then, presents one or more experts and judges and juries must decide which expert to believe. Both judges and juries are placed in a situation in which they are called upon to arbitrate among competing academic and scientific theories and methods in deciding what expertise will "assist" them in their determination of the facts. And "science" is thus presented as something which itself is an adversary enterprise. It is not uncommon for the very competition itself to undermine the authority of the expert and to call into question the entire enterprise of expert witnessing.

As a general matter, the evidentiary rules governing expert testimony have developed in the two most frequent types of US trials, personal injury cases and criminal cases, although experts are used in many different kinds of trials. Political concern has been expressed that in personal injury trials too many plaintiffs are winning large jury awards based in shoddy scientific evidence offered by persons who are professional trial experts without strong continuing scientific lab experience and knowledge, while, in criminal cases, defense attorneys increasingly routinely use expert testimony to challenge the reliability of the scientific basis of forensic evidence, including, for example, even long-accepted fingerprint and hand-writing evidence, thereby undermining prosecutors' cases. ${ }^{14}$ The history of the use of DNA evidence is particularly instructive as it has moved within the last decade from never allowed to almost universally acceptable. Statutes providing a right to state-funded DNA evidence for indigent clients are being promoted.

13. This rule is derived from the Daubert decision. Daubert v. Merrell Dow Pharmaceuticals, 522 US 136, 1997.

14. For a discussion of new types of forensic science and existing evidentiary law see, for example, Erin Murphy, "The New Forensics: Criminal Justice, False Certainty, and the Second Generation of Scientific Evidence", California Law Review, 95, 2007, 721-797. 
Most evidentiary law about expert testimony presupposes a model of expert knowledge based primarily in the natural sciences. While there are serious epistemological difficulties with natural science evidence and issues about the capacity of judges and juries to evaluate all expert evidence, qualitative social-scientific, or humanistic, rather than natural scientific or quantitative social-scientific, expert testimony has always fit uneasily within this body of law. ${ }^{15}$ While positivist understandings of law and positivist understandings of the natural sciences may seem to come together comfortably, the range of both disciplinary approaches and types of evidence in the humanities and qualitative social sciences makes courts more uneasy. Persistent issues include the qualifications of experts, the methods they use, and the kinds of opinions they can give. Social scientific and humanistic knowledge about human behavior is seen to be much closer to the kinds of common sense judgments that are reserved for the jury or judge and to blur the lines of authority. At the extreme, the very relevance of such knowledge is at issue.

The form of testimony is also an issue. In some courts, experts testify both through written reports and through in-court spoken testimony. The written report is often cast in the form of an affidavit, a form of lawspeak that demands a declarative style which enacts a level of certainty about matters with which many academic experts are uncomfortable. In-court testimony presents other issues. Testifying in response to questions from lawyers makes it difficult for experts to fill out and qualify their testimony in a way that both fits with their disciplinary epistemology and is ultimately persuasive. The very narratives that justify the opinion are often excluded. The legal question will rarely be exactly parallel to the expert's research question. It is in the gap between the two that the question of relevance and materiality falls. Finally, cross-examination often focuses on distracting and sometimes extraneous efforts to catch up the expert in small contradictions or ambiguities — or even contrived deficiencies of trainingwithout the possibility of full explanation.

\section{Religion expertise}

Who is an expert on religion? Some religious traditions have built-in experts, that is, they have elders or theologians or shamans, persons with knowledge and office with whom political authorities have historically consulted or negotiated,

15. For a discussion of evidence on gender differences in an employment discrimination case, see Joan Scott, "The Sears Case", in Gender and the Politics of Difference, New York, Columbia University Press, 1999. For classic discussions of the anthropologist as expert witness in US courts, see Lawrence Rosen, "The Anthropologist as Expert Witness" American Anthropologist, 79, september 1977, 555-578; James Clifford, "Identity in Mashpee”, in James Clifford, (ed.), The Predicament of Culture: Twentieth Century Ethnography, Literature, and Art, Cambridge, Harvard University Press, 1988, 277-348. 
and to whom they have sometimes submitted, about religion that comes into conflict with governance. Some modern states have offices or ministries that fill this function, either formal remnants of earlier established churches or the various hybrid descendants of such churches, but growing religious diversity (or perhaps more accurately growing acknowledgment of religious diversity) continues to challenge the practicality of such efforts. ${ }^{16}$ For countries with strong separationist or secularist commitments, and radically egalitarian religious communities, such as the US, states in which such a government ministerial function is lacking, expertise in religion is often diffuse and unorganized and accessed by government on a piecemeal basis. Such expertise may even be rejected as inherently illiberal so that what counts as religion comes to be defined in pseudoscientific or vernacular terms.

The US has no centralized office for regulating religion and no single definition of religion for legal purposes. Neither do the individual states. Within the very broad and often ambiguous and contradictory parameters set by the Supreme Court, individual agencies at the state and federal level, including taxing authorities, correctional institutions, the military services, zoning authorities, law enforcement, etc., make their own decisions about what counts as religion for the purpose of implementing the thousands of US laws that take account of religion. This practical lack of consensus about what counts as expertise in religion is exacerbated by the lack of consensus among those who study religion in the US as to what counts as religion. Notwithstanding this lack of agreement and the decentralized decision-making about religion by legal authorities in the US, however, religion experts have testified in American trials for a long time, Christian theologians, as well as academic scholars of various religious traditions, and of comparative religions-historians, sociologists and anthropologists. They testify in every kind of case, civil and criminal.

Religion may become a material issue in US law cases founded in the religion clauses of the First Amendment to the US Constitution, ${ }^{17}$ in those founded in the thousands of federal, state, and local statutes that explicitly make religion relevant, including conscience clauses providing health care workers the right to refuse to serve in certain kinds of circumstances, and in a further class of cases in which one of the parties makes religion relevant, such as in the probate of a will or in a child custody case-or even in the case of what is sometimes called

16. See the following essay describing the efforts of modern states to manage religion through government ministries: Tim Jensen, "When is Religion, Religion and a Knife, a Knife-and Who Decides? The Case of Denmark"; Markus Dressler, “The Religio-Secular Continuum, or Secular Law as a Theological Discourse in Turkey”, in W. F. Sullivan, R. A. Yelle, and M. Taussig-Rubbo, (eds.), After Secular Law, Stanford, Stanford University Press, 2011.

17. The First Amendment to the United States Constitution provides, in relevant part, "Congress shall make no law respecting an establishment of religion or prohibiting the free exercise thereof...” 
the cultural defense in a criminal trial. A largely dispersed and ad hoc set of practices governs the admissibility of experts on religion in these cases. For the most part, because competent teaching about religion is rare in public schools in the US, ${ }^{18}$ and because expertise in religion is constitutionally suspect, American lawyers and judges are generally poorly educated about religion and they have little capacity to understand religious issues as they pertain to legal questions, to competently present or evaluate them in court, or to select and interact with religious experts.

Because of the ambivalence of Americans with respect to expertise in religion, because of their general unfamiliarity with the social scientific study of religion, and because any and all defining of religion by US law is unconstitutionally establishmentarian, the argument has been made that expertise about religion is simply not necessary. ${ }^{19}$ A person's constitutional right to determine his own religious identity, it is said, proscribes the use of expert testimony on such a subject. Yet expert testimony about religion is, in fact, often offered in court and often cited in judicial opinions. While there is a great deal of research on the use of expert testimony generally, its reliability and its effect on jury decisionmaking, there is very little academic theorizing of these issues as they pertain to religion.

Historical facts about, and opinions on, religion may be produced at trial or, even more problematically, simply introduced by a judge, based in his own, or his clerks', research, when preparing his decision and writing his opinion. As an example of the latter, in the well-known nineteenth century polygamy case, Reynolds $v$. US ${ }^{20}$ the first Supreme Court case interpreting the meaning of the Free Exercise clause, the Chief Justice of the United States used the writing of a prominent nineteenth century polemicist, Francis Lieber, to support his opinion that "[p]olygamy has always been odious among the northern and western nations of Europe, and, until the establishment of the Mormon Church, was almost exclusively a feature of the life of Asiatic and of African people." 21

18. The Supreme Court observed in Abington v. Schempp, 374 US 203, 1963, that while public schools in the US were prohibited from requiring Bible reading at the start of each school day, schools might teach "objectively" "about" religion in classes such as history or literature. Religious studies has flourished at the college and university level in the US in both public and private institutions since that time, but teaching about religion at the elementary and secondary school levels remains very undeveloped in the US, both because of popular understandings of the religions clauses that diverge from that of the Court and because primary and secondary schools are controlled locally and therefore subject to local politics. In practice, politically distinguishing between teaching religion and teaching about religion has been almost impossible to achieve. Americans prefer children to learn about religion-and sex-at home.

19. See discussion of such a view expressed by the US Court of Appeals for the Eighth Circuit in Winnifred Fallers Sullivan, Prison Religion, 217-18.

20. 98 US 145,1878 .

21. 98 US at 164 . 
The Reynolds decision famously held that the Free Exercise clause of the First Amendment protects belief absolutely but not practice; that is, in the words of the Court, that "Congress was deprived of all legislative power over mere opinion [by the First Amendment], but was left free to reach actions which were in violation of social duties or subversive of good order." The Chief Justice quoted its expert in religion to support its conclusion that polygamy was contrary to good order: "Professor Lieber says, polygamy leads to the patriarchal principle, and which, when applied to large communities, fetters the people in stationary despotism, while that principle cannot long exist in connection with monogamy." Lieber also linked the necessity of monogamy to theories of white racial superiority. ${ }^{22}$

In Reynolds, then, the US Supreme Court found it not error for the trial court to have charged the jury that there must have been a criminal intent, but that if the defendant, under the influence of a religious belief that it was right - under an inspiration, if you please, that it was right-deliberately married a second time, having a first wife living, the want of consciousness of evil intent-the want of understanding on his part that he was committing a crime-did not excuse him, but the law inexorably in such case implies the criminal intent. ${ }^{23}$

This harsh dismissal of the force and relevance of religious motivation, interestingly diverging from the insanity defense, for example, remains good constitutional law in the United States today. Reynolds was recently affirmed in Employment Division v. Smith, in which the Court held that religious motivation to use peyote did not provide a constitutional justification for violation of laws regulating controlled substances. ${ }^{24}$ In fact, even outside of constitutional cases, in spite of much rhetoric and the passing of numerous laws designed to insulate religiously motivated persons from prosecution for actions they have taken as religious persons, US courts are generally reluctant to excuse people judicially from compliance with the law on the basis of religious justification. ${ }^{25}$ And yet,

22. Legal efforts to end polygamy among Mormon communities continues today. See, for example, concerning the 2008 raid by Texas authorities on the Yearning for Zion Ranch owned by the Fundamentalist Latter Day Saints, Winnifred Fallers Sullivan, "Reforming Culture: Law and Religion Today" in Robert Orsi, ed., Cambridge Companion for Religious Studies, Cambridge, Cambridge University Press, 2011.

23. 98 US at 162 .

24. See Employment Division v Smith 494 US 872, 1990. Speaking phenomenologically, legal philosopher Cathleen Kaveny has suggested in the context of conscience clauses for health care workers that religious motivation might be productively analogized to disability under the Americans with Disabilities Act. Patricia Townsend Meador Lecture. Vanderbilt University, 3 january 2011, http://calendar.vanderbilt.edu/calendar/2011/03/01/patricia-townsend-meadorlecture-m-cathleen-kaveny-jd-phd.131703

25. For a discussion of these issues in the Canadian context, see Benjamin L. Berger, "Moral Judgment, Criminal Law and the Constitutional Protection of Religion," Supreme Court Law Review, 40, 2008, 513, 537-550. 
while this apparently secularizing inhibition is explicit under the Reynolds and Smith decisions, American law continues to be implicitly influenced by religious anthropologies in a wide range of areas, including the definitions of crime and the imposition of punishment, laws regulating social services and business, and the law of marriage, although much work has been done to expose the religious assumptions and structures underlying the administration of family law in the US. ${ }^{26}$

To illustrate the use of expert evidence about religion in the contemporary American courtroom, I will discuss briefly the expert evidence in what are termed, in US constitutional terms, a Free Exercise case and an Establishment Clause case. The two cases are interesting in evidence terms, not in doctrinal terms. The epistemological difficulties considered in this article cut across doctrinal differences about the proper interpretation of the First Amendment.

In Warner $v$. Boca Raton, ${ }^{27}$ I was one of five religion experts called to testify about the nature of the practices at issue in the case. ${ }^{28}$ The plaintiffs in the Warner case were a group of families whose relatives had been buried in a municipal cemetery in Boca Raton, Florida. Cemetery regulations limited memorialization to small flat plaques, flush with the ground, regulations that were designed to facilitate lawn maintenance and the movement of heavy equipment for grave-digging but which were also consistent with trends in cemetery design. Over a couple of decades in the 1980's, cemetery workers allowed several hundred families-ordinary American Protestants, Catholics, and Jews-to build small home-made "shrines" on the graves, in apparent violation of the regulations. The City subsequently changed its policy and decided to start enforcing the rules by removing existing grave decorations. The plaintiffs claimed that both the cemetery rules and the city's enforcement of the rules violated the free exercise clause of the First Amendment to the US Constitution, the Florida Constitution, and the Florida Religious Freedom Restoration Act. ${ }^{29}$ Because the constitutional issue was fairly clearly foreclosed by recent US Supreme Court decisions interpreting the Free Exercise clause, the principal issue at trial was whether what the plaintiffs had done on the graves was "religious" within the meaning of the new Florida statute prohibiting government from "substantially burdening the practice of religion".

26. See, for example, Janet Jakobson and Ann Pellegrini, Love the Sin: Sexual Regulation and the Limits of Religious Tolerance, New York, New York University Press, 2003; Mary Anne Case, "Marriage Licenses", University of Minnesota Law Review, 89, 2005, 1758-1797.

27. Warner v. Boca Raton, 64 F. Supp. 2d 1272, 1999.

28. See Winnifred Fallers Sullivan, The Impossibility of Religious Freedom, Princeton, 1995 , for a description and analysis of the trial.

29. The Florida Act was one of a series of state statutes that were passed following the declaration by the Supreme Court that the federal RFRA was unconstitutional as applied to the states. Fla. Stat. $\mathbb{S}$ 761.01, et seq. See Boerne v. Flores, 521 US 507, 1997. 

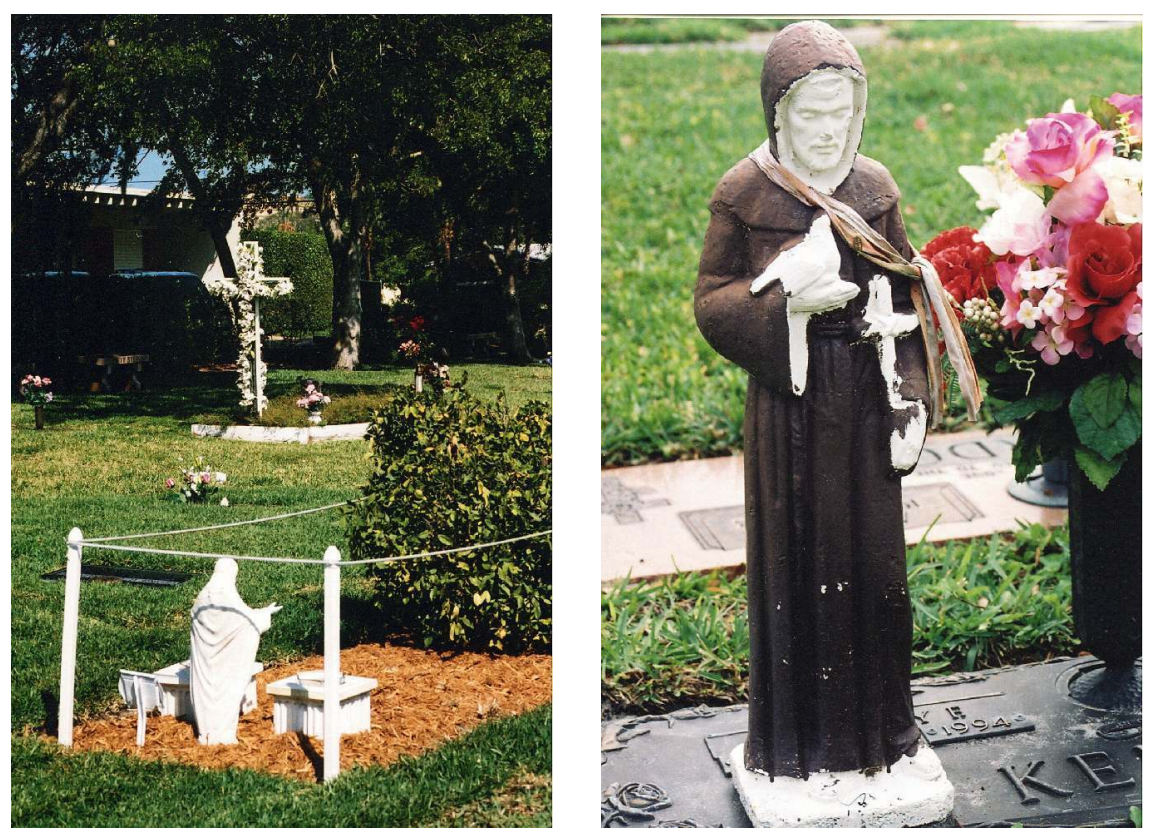

Non-conforming grave decorations.

Boca Raton Municipal Cemetery, Boca Raton, Florida, 2004

While the Warner case is not a doctrinally significant decision, it is particularly interesting from an evidentiary standpoint because five religion experts testified. Three academic experts in religion testified for the plaintiffs and two for the City of Boca Raton, each offering an opinion as to whether the grave decorations built by the plaintiffs were religious. We had five different theories of what constitutes religion and whether the plaintiffs' activities should be so described. In the end, the judge developed his own theory of religion in his opinion in the case, using his own religious knowledge as a member of a conservative Presbyterian Church as well as picking and choosing among the views of the courtroom experts. There was no jury. Roughly speaking, the religion experts who testified for the plaintiffs in the Warner case, a church historian, an expert in Jewish law, and me, a comparative religion scholar, testified that the plaintiffs' practices, although not mandated by explicit written religious law, were practices rooted in and consistent with the religious narratives expressed by the plaintiffs in their own testimony, such that their prohibition might constitute a "substantial burden" to the plaintiffs. The religion experts for the defendants, both scholars of comparative religions, offered formal structured models of religion that would permit the judge to locate the plaintiffs' practices along a spectrum from "high" or "central" religious practices to "low" or "peripheral" religious practices, concluding respectively that the popular religious practices evident in the cemetery "shrines" were "low" or "peripheral," and therefore did not rise to a 
level that deserved legal protection. The judge developed his own standard, partly through a blending of the theories of the two experts for the defendants, ultimately finding that the plaintiffs' practices were motivated not by religion but by what he called "purely personal preference." His decision was upheld on appeal.
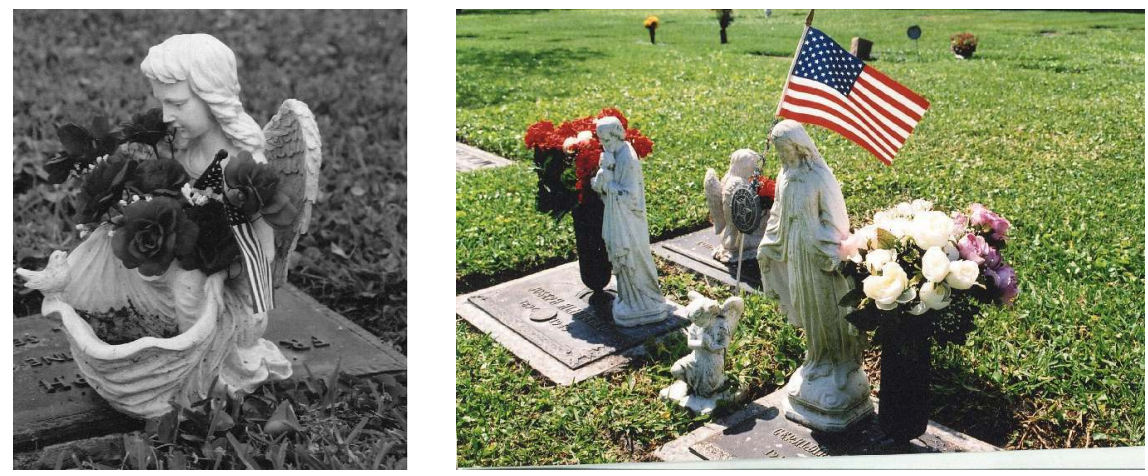

Non-conforming grave decorations.

Boca Raton Municipal Cemetery, Boca Raton, Florida, 2004

The judge in the Warner case made clear in his opinion that he considered himself to be as much an expert in religion as any of the witnesses, notwithstanding his lack of academic training in religion. Indeed, he revealed a deep and very Protestant skepticism about the significance of the history of Christian burial offered by the church historian as well as the methods of Jewish legal practice employed by the Orthodox rabbinical expert, substituting instead his own lay evangelical understanding of the importance of Christian history and how scripture should be read. In doing so, he arguably refused to implement the evident intent of the Florida statute to protect religious persons from laws that impinge on their religious practices, whether conventional or not. ${ }^{30}$ Whatever one's position on issues of doctrine or statutory interpretation, the judge's use of expert testimony in the Warner case is troubling from an evidentiary standpoint. Religious studies as a field is deeply divided on defining religion. Indeed one might say it is constituted centrally by an argument over what counts as religion and whether what counts as religion can be understood apart from a particular political consensus on the issue. ${ }^{31}$ If each American is entirely free to make her own decision about her religious standpoint and activity, in what sense can religious expertise be legally "scientific", or even "assist" the trier of fact?

30. The Definitions section of the Act defines an exercise of religion as "an act or refusal to act that is substantially motivated by a religious belief, whether or not the religioius exercise is compulsory or central to a larger system of religious belief" $\mathbb{7} 761.03(3)$.

31. Classic articulations of this problem include Jonathan Z. Smith, "Religion, Religions, Religious", in Mark Taylor, (ed.), Critical Terms for Religious Studies, Chicago, University of Chicago Press, 1998. 
The Warner case, like the Reynolds case discussed above, concerned what is known in the US as a free exercise issue, that is, the legal question of when a person is exempt from laws that apply to everyone else because her action is religiously motivated. Experts in free exercise cases are usually testifying about a particular religious tradition, supporting a party's claim to be acting consistently with her religious tradition. The testimony of all of the expert witnesses in the Warner case revealed the gap that may open in these cases between the expert's description of a particular religious tradition and the witness' own version of that tradition. The capacity of the court to adjudicate the orthodoxy of the witness' practices is deeply problematic in a country in which religion is disestablished and the free exercise of religion is guaranteed.

The other religion "clause" in the First Amendment is the Establishment Clause. Cases brought under the Establishment Clause address the question, when is the government prohibited from acting because its actions constitute an unconstitutional "establishment" or favoring of religion? An unconstitutional religious establishment has been understood to occur not only when government officially institutionalizes a particular church as the official state church, but also in a range of situations in which government can be understood to "endorse" one religion over another, or even religion over non-religion. Academic experts in establishment clause cases are testifying to the religiousness or secularity of activities of the government (or of agents of the government). Most Establishment Clause cases involve schools because historic anti-Catholic prejudice in the US has made schools a focus of political and constitutional concern, but there also are a set of cases concerning directly the possible religiousness of symbols or practices of elected officials, such as government recognition of Christmas as a national holiday or the placing of images of the Ten Commandments in public places as a gesture of moral exhortation. ${ }^{32}$

Schools in the US are managed primarily at the local, rather than the national, level. In a recently highly publicized case, a federal district court in Pennsylvania held that a local school board's recommendation to its students that it consider Intelligent Design ${ }^{33}$ as an explanation for the fossil record, was unconstitutional under the Establishment Clause. ${ }^{34}$ The legal charge in Kitzmiller was that the local school board was "establishing" religion within the meaning of the First

32. See, for example, Lynch $v$. Donnelly, 465 US 668, 1983.

33. "Intelligent design", in its simplest sense, refers to the belief that the beauty and complexity of the natural world is itself evidence of an intelligent designer, undercutting an argument from natural selection. That observation has, at various times in history, been offered as one proof for the existence of God. Intelligent Design as a movement came into being in the United States in response to the teaching of evolution in public school biology classes and in the wake of the failures of earlier anti-evolution efforts.

34. Kitzmiller v. Dover Area School District, 400 F. Supp. 2d 707, 2005. See also this author's article, "Being Human: Negotiating Religion, Law, and Science in the Classroom and the Courtroom”, in Elizabeth Mertz, (ed.), The Process of Translation: Law, Social Science, and New Legal Realism, Cambridge, Cambridge University Press, 2011. 
Amendment when it recommended that its students read Of Pandas and People, ${ }^{35}$ a book promoting the theory of intelligent design (ID) as an explanation for human origins superior to Darwinian evolutionary theories. Many expert witnesses at the trial testified concerning intelligent design. Echoing the standard for scientific evidence under the Federal Rules of Evidence, Judge Jones, the judge in the Kitzmiller case, found that intelligent design is not science but religion because science is defined by methodological naturalism and ID lacks an empirical foundation in the scientific method.

Judge Jones' opinion, in contrast to the judge in the Warner case seems to use the evidentiary rules respecting expert testimony to determine what constitutionally counts as religion, rather than starting with a definition of religion. That is, if it does not meet the Daubert standard, then it must not be scientific and therefore must be religion. He also found, though, that ID is not merely not science. It is a deliberate fraud. ID, while it markets itself as science, is really, according to the expert witnesses and the judge, "stealth" religion — religion that dare not speak its name.

For most academic scholars of American religion, ID, and the question of its "real" purpose, would be considered an artifact of American populism and of the US culture wars. Whether ID is religion within the meaning of the Establishment Clause is a different question. To teach ID in science classes may be to teach scientific nonsense, but, one might argue, it is not therefore to teach religion. Proponents of ID are anti-establishment in the sense of being against big government and big science. Some of them are striving to make space for a biblical account of human origins. But ID has no specific religious content. Its proponents have learned that lesson from the fate of creationism. ${ }^{36}$

Opponents of ID are exactly the elites about whom many Americans are suspicious. Judge Jones' decision in the Kitzmiller case was underwritten by the various experts who testified at the trial. Among them was a Christian theologian who described ID as bad theology, the product, in effect, of religious ignorance. It was not just bad science, he said, it was also bad religion.

A brief review of the facts in the case. On October 18, 2004, the Kitzmiller defendants, the Dover Area School Board of Directors, ${ }^{37}$ had passed the following resolution by a 6-3 vote:

Students will be made aware of gaps/problems in Darwin's theory and of other theories of evolution including, but not limited to, intelligent design. Note: Origins of Life is not taught.

35. Percival Davis and Dean H. Kenyon, Of Pandas and People: The Central Question of Biological Origins, Dallas, TX: Haughton Publishing, 1989.

36. Creationism was also promoted as a substitute for teaching evolutionary theory in US classrooms, and also successfully challenged in the courts under the Establishment Clause. Edwards v. Aguillard, 482 US 578, 591, 1987.

37. The Dover area school district encompasses an area around York, Pennsylvania, west of Philadelphia. 
A month later, the Dover School Board announced that, beginning in January 2005, teachers would be required to read the following statement to students in the ninth grade biology class at Dover High School:

The Pennsylvania Academic Standards require students to learn about Darwin's Theory of Evolution and eventually to take a standardized test of which evolution is a part.

Because Darwin's Theory is a theory, it continues to be tested as new evidence is discovered. The Theory is not a fact. Gaps in the Theory exist for which there is no evidence. A theory is defined as a well-tested explanation that unifies a broad range of observations. Intelligent Design is an explanation of the origin of life that differs from Darwin's view. The reference book, Of Pandas and People, is available for students who might be interested in gaining an understanding of what Intelligent Design actually involves. With respect to any theory, students are encouraged to keep an open mind. The school leaves the discussion of the Origins of Life to individual students and their families. As a Standardsdriven district, class instruction focuses upon preparing students to achieve proficiency on Standards-based assessments.

While ridiculed by many academics, ${ }^{38}$ the statement seems a genuine, if somewhat untutored and unscientific, in the professional sense, effort, to explain to students how science education works and how they intend to handle local concerns about the teaching of evolution and the proper role of families in child raising.

The plaintiffs in the Kitzmiller case were a group of parents challenging the school board's required statement as an unconstitutional establishment of religion. The plaintiffs argued that Intelligent Design, while presented by the school board as simply another scientific theory explaining the known facts about the fossil record, was in fact a religious program strategically masked as a scientific one. Among the experts supporting their theory about the essentially religious and non-scientific nature of the school board's actions, and of the unambiguous distinction between religion and science, was John Haught, professor of theology at Georgetown University. Haught expressed the view that ID is "an essentially religious idea." ${ }^{39}$ Explaining that intelligent design can be traced genealogically to a line of Christian theology beginning with Thomas Aquinas, Haught concluded:

38. For example, at a plenary lecture on August 20, 2010 at the International Association for the History of Religion XX World Congress, at which this author was present, Susan Haack, Professor of Philosophy at the University of Miami, and a leading philosopher of science, described the Dover School Board's statement as "poorly written, ill-informed, stupid, [and] sneaky", and offered the opinion that "the theory of evolution is indisputably logically incompatible with a literal reading of the book of Genesis." Susan Haack, "Cracks in the Wall, A Bulge Under the Carpet: The Singular Story of Religion, Evolution, and the US Constitution" (unpublished but provided to the author in manuscript).

39. Many academic scholars of religion today would be skeptical of the notion that there are any ideas that are "essentially" religious, believing rather that what counts as religion depends on the context. See, among others, Jonathan Z. Smith, Relating Religion: Essays in the Study of Religion, Chicago, 2004. 
ID tries to squeeze what is undeniably a supernatural cause, intelligent design, into an explanatory slot where only natural causes are methodologically permissible... Throughout the modern period scientific method has refused to use categories such as purpose, God, intelligence, value, meaning, importance, etc., and has attempted to understand all phenomena in a very limited impersonal and indeed physical way... Theologically, moreover, major traditions maintain that if God influences and interacts with the created world it cannot be in the same way that physical causes operate. From the point of view of the most prominent theologians, therefore, not only is ID poor science, it is also appalling theology.

"Major" traditions and "the most prominent" theologians have worked it out, according to Haught. No "good scientist" would indulge in professional speculations on ultimate causes. No good theologian would believe in miracles or assert that God intervenes in history. Genealogy, according to Haught, establishes the essential nature of things. ${ }^{40}$

Haught is a liberal theologian. The practice of having "liberal" theologians either testify or be cited in American courtrooms as experts in religion is longstanding. Paul Tillich has been cited for the proposition that religion is about "ultimate concern" and therefore conscientious objection to serving in the military should be respected not only if it is founded in the traditions of a pacifist church, but also if it is founded in a non-religious philosophy that takes the place of religion for an individual, US v. Seeger. ${ }^{41}$ In another evolution case, McLean v. Arkansas, ${ }^{42}$ the well-known liberal Protestant theologian, Langdon Gilkey, served as an expert witness against the creation science statute in Arkansas. He also used the Protestant Christian theology of Paul Tillich to define religion and to critique creation science. ${ }^{43}$ The fit between liberal theology and science is very cozy. In contrast, others have argued that ID, as Colin Jager explains, is another way to be religiously modern, rooted as it is in romantic rather than enlightenment sensibilities. ${ }^{44}$

How should courts determine when grave decorations are religious or whether schools are teaching religion in the absence of politically sanctioned authorities who are charged with these tasks? In the US the answer to these questions is singularly underdetermined and therefore singularly subject to continuous political negotiation. There is no public office charged with officially managing religion and education is subject to the direction of popularly elected school boards.

40. Much of modern thought would, of course, be disqualified under this test.

41. 380 US 163, 1965.

42. 529 F. Supp. 1255 (ED Ark. 1982).

43. Langdon Gilkey wrote a book about his experiences. Creationism on Trial: Evolution and God at Little Rock, Charlottesville, University of Virginia Press, 1985.

44. See, for example, Colin Jager, The Book of God: Secularization and Design in the Romantic Era, Piladephia, University of Pennsylvania Press, 2006. 


\section{Conclusion}

Legal comprehension of religion in the US is largely inchoate. Combining a political attitude of respectful and neutral support for religious freedom with a mandate not to favor any religion is very difficult, as states around the world are discovering. Individual Americans are understood to be entirely free to define their own religious lives as they please. When law appears to give religiously motivated persons special privileges over those who are not so motivated or forbids government establishment of religion, courts are left with the difficult problem of line drawing. ${ }^{45}$ It is not clear that academic expertise in religion properly has any useful role to play in court. ${ }^{46}$

I served as an expert witness in an Establishment Clause case several years ago (Americans United $v$. Prison Fellowship Ministries ${ }^{47}$ ). I testified to what I thought to be a fairly unremarkable opinion concerning the evangelical religious character of an in-prison rehabilitation program, InnerChange Freedom Initiative, operated by Charles Colson's Prison Fellowship Ministries, an opinion that would be shared, I believed, by most other scholars of American religion. Indeed, I believed that they would so regard themselves. I gave no opinion on the constitutional question before the Iowa court. Opinions on legal issues are usually reserved for the judge in American courts. ${ }^{48}$

In the district court, the defendants in the $A U v$. PFM case unsuccessfully tried to prevent my testifying by challenging my qualifications to be an expert under federal law. ${ }^{49}$ But, more significantly, in the appeal of the decision to the US Court of Appeals for the Eighth Circuit, they successfully challenged the admissibility of my testimony, arguing that the Constitution prohibits an American court's hearing from any expert in religion. They explained: "It is well established, in numerous other contexts, that courts should refrain from trolling through a person's or an institution's religious beliefs. The district court abused its discretion, as the professor's testimony is not relevant." 50 While the Court of Appeals substantially affirmed the trial court's decision in all important respects,

45. There are American First Amendment theorists who believe that common sense understandings of religion can do this work with sufficient precision to continue to support the work of the courts in interpreting and implementing such laws. See, for example, Kent Greenawalt, Religion and the Constitution, Vols. I and II, Princeton, Princeton University Press, 2006.

46. I do think the academic study of religion has a useful role to play in education.

47. Americans United for Separation of Church and State v. Prison Fellowship Ministries (AU v. PFM), 432 F. Supp. 2d 862 (SD Iowa 2006).

48. See W. F. Sullivan, Prison Religion: Faith Based Reform and the Constitution, Princeton, Princeton University Press, 2009, for a discussion of the PFM case.

49. Their argument was that I lacked relevant expertise because I had not visited the prison and interviewed the prisoners but instead had based my opinion on reading the documents produced by Prison Fellowship describing the program, including manuals and lesson plans, as well as on my knowledge of American religious history.

50. Americans United for Separation of Church and State v. Prison. Fellowship Ministries, 509 F. $3^{\text {rd }} 406,2008$. 
including the trial court's conclusion that the state's contract with the prison program violated the Establishment Clause, the Court held that my testimony was not constitutionally "relevant," as a matter of evidentiary law, because such expertise is inherently establishmentarian.

The AU $v$. PFM opinion finding the admission of my testimony to be error will not end the use of religious experts in US courts because it has little precedential value with respect to evidentiary decisions by other district court judges. But the anxiety expressed reflects common American prejudices against expertise in religion matters and in favor of individual decision-making about religion, prejudices rooted in the long history of US disestablishment and intensified by broader concerns about expert-witnessing in US courts.

Today in the US, religious freedom increasingly means that individuals define religion for themselves-and that no religious expert has any public authority, legal or political, to override that reality. The result, perhaps ironically, is that the rejection of one form of "establishment," that is established religious authority is rejected in favor of another form of "establishment," that is increased power in the political establishment to define religion. One can see that dynamic at work in the PFM $v$. AU case. Expert testimony was rejected in favor of judicial limits on religious practice in the name of individual freedom. ${ }^{51}$ Governments may make laws that make it difficult to do what your religion requires of you but they cannot tell you what your religion is. ${ }^{52}$

\author{
Winnifred F. SULLIVAN \\ University at Buffalo Law School \\ The State University of New York \\ wfs2@buffalo.edu
}

\title{
Bibliography
}

Berger Benjamin L., 2008, "Moral Judgment, Criminal Law and the Constitutional Protection of Religion”, Supreme Court Law Review, 40, pp. 513-550.

Burns Robert P., 1999, A Theory of the Trial, Chicago, University of Chicago Press.

-, 2011, "Social Science and the Ways of the Trial Court: Possibilities of Translation", in Mertz E., Ford W., (eds.), The Process of Translation: Law, Social Science, and New Legal Realism, Cambridge, Cambridge University Press.

51. For an extensive exploration of this theme in US law, see Fabienne Randaxhe, "De 'l'exception religieuse' états-unienne”, Archives de sciences sociales des religions, 122, 2003. (URL: http://assr.revues.org/1515)

52. A particularly interesting extension of this notion is evident in the fact that under the 1990's Native American Graves Protection and Repatriation Act (NAGPRA), American courts are required to treat indigenous evidence as equal to scientific evidence. See the work of Gregory Johnson, esp. Sacred Claims: Repatriation and Living Tradition, Charlottesville, University of Virginia Press, 2007. 
Clifford James, 1988, "Identity in Mashpee", in Clifford J., (ed.) The Predicament of Culture: Twentieth Century Ethnography, Literature, and Art, Cambridge, Harvard University Press, pp. 277-348.

EDmond Gary, 2002, "Whigs in Court: Historiographical Problems with Expert Evidence", Yale Journal of Law and Humanities, 14, pp. 123-75.

Fradella Henry F., 2003, "A Content Analysis of Federal Judicial Views of the Social Science 'Researcher's Black Arts”, Rutgers Law Journal, 35, pp. 103-170.

Galanter Marc, 2004, "The Vanishing Trial: An Examination of Trials and Related Matters in Federal and State Courts", I-3, J. Empirical Legal Studies, pp. 459-570.

GiLkey Langdon, 1985, Creationism on Trial: Evolution and God at Little Rock, Charlottesville, University of Virginia Press.

Grann David, 2009, “Trial by Fire: Did Texas Execute an Innocent Man?” The New Yorker, September 7, pp. 42-63.

GreEnawalt Kent, 2006, 2008, Religion and the Constitution, Vol. I. Free Exercise and Fairness; Vol. II. Establishment and Fairness, Princeton, Princeton University Press.

Jager Colin, 2007, The Book of God: Secularization and Design in the Romantic Era, Philadelphia, University of Pennsylvania Press.

Jakobson Janet, Pellegrini Ann, 2003, Love the Sin: Sexual Regulation and the Limits of Religious Tolerance, New York, New York University Press.

Jensen Tim, 2011, "When is Religion, Religion and a Knife, a Knife-and Who Decides? The Case of Denmark”, in Sullivan W. F., Yelle R. A., Taussig-Rubbo M., (eds.), After Secular Law, Stanford, Stanford Law Books.

JoHnson Gregory, 2007, Sacred Claims: Repatriation and Living Tradition, Charlottesville, University of Virginia Press.

LEARNED HAND Billings, 1901, "Historical and Practical Considerations Regarding Expert Testimony", 15, Harvard Law Review, 40-xx.

Lilly Graham C., 2006, Principles of Evidence, Saint Paul, West Publishing.

Noll Mark, 1995, The Scandal of the Evangelical Mind, Grand Rapids, Eerdmans.

MerTz Elizabeth, (ed.), 2011, The Process of Translation: Law, Social Science, and New Legal Realism, Cambridge, Cambridge University Press.

Murphy Erin, 2007, "The New forensics: Criminal justice, false certainty, and the second generation of scientific evidence", California Law Review, 95, pp. 721-797.

Orsi Robert, (ed.), 2011, Cambridge Companion for Religious Studies, Cambridge, Cambridge University Press.

Rosen Lawrence, 1977, “The Anthropologist as Expert Witness”, American Antropologist, 79, pp. 555-578.

ScotT Joan, 1999, "The Sears Case", in Gender and the Politics of Difference, New York, Columbia University Press.

SMITH Jonathan Z., 2004, Relating Religion: Essays in the Study of Religion, Chicago, University of Chicago Press.

Sullivan Winnifred Fallers, 2005, The Impossibility of Religious Freedom, Princeton, Princeton University Press.

-, 2009, Prison Religion: Faith-based Initiatives and the Constitution, Princeton, Princeton University Press.

TAYlor Mark, 1998, Critical Terms for Religious Studies, Chicago, University of Chicago Press. 
60 - ARChives De SCIENCES SOCIALES DES RELIGIONS

\section{Abstract}

This article examines how academic experts contribute to the discussion of court cases concerning the defense of religious freedom in the US Based on a study of relevant cases in which the scope of the first amendment has been debated, and relying on her own experience as an expert in some of these court cases, the author addresses the question of who is legitimate to define what counts or not as religious. She also studies the ambivalent relation of the American public to academic expertise. While some consider the role of experts as necessary to the formation of fair decisions, others view it as an obstacle to the expression of people's will.

Key words: academic and judicial expertise, First Amendment, religious freedom, elitism, secularity.

\section{Résumé}

Cet article étudie comment les experts universitaires contribuent au règlement des affaires portées devant les tribunaux américains concernant la protection de la liberté religieuse. À partir de certains cas significatifs où les limites et la portée du premier amendement ont été débattus, et en s'appuyant sur des éléments tirés de son expérience d'experte sollicitée par les tribunaux, l'auteure traite de la question de savoir qui est légitime et habilité à définir ce qui est religieux ou non religieux. Elle étudie également le rapport ambivalent du public américain avec l'expertise, à la fois considérée comme garantie d'une décision éclairée et comme potentiellement contraire à la volonté populaire.

Mots-clés: expertise juridique et universitaire, premier amendement, liberté religieuse, élitisme, laïcité.

\section{Resumen}

Este artículo examina la contribución de los expertos universitarios a la regulación de los asuntos llevados ante los tribunales americanos en relación con la protección de la libertad religiosa. A partir de un estudio de ciertos casos significativos donde los limites y el alcance de la primera enmienda han sido debatidos, y apoyándose igualmente sobre elementos tomados de su experiencia de experta solicitada por los tribunales, la autora trata la cuestión del saber que es legítimo e idóneo para definir aquello que cuenta como religioso o no religioso. Ella estudia también la relación ambivalente del público americano en relación con las pericias, a la vez consideradas como garantía de una decisión ilustrada y como siendo potencialmente contraria a la voluntad popular.

Palabras clave: pericias jurídicas y universitarias, primera enmienda, libertad religiosa, elitismo, laicidad. 